Article

\title{
Preliminary Insight into Winter Native Fish Assemblages in Guadiana Estuary Salt Marshes Coping with Environmental Variability and Non-Indigenous Fish Introduction
}

\author{
Renata Gonçalves ${ }^{1, *}$, Maria Alexandra Teodósio ${ }^{1}$, Joana Cruz ${ }^{1}$, Radhouan Ben-Hamadou ${ }^{2}$, \\ Ana Dulce Correia ${ }^{3}$ and Luís Chícharo ${ }^{4}$ \\ 1 CCMAR, Centro de Ciências do Mar, Campus de Gambelas, 8005-139 Faro, Portugal; \\ machichar@ualg.pt (M.A.T.); jcruz@ualg.pt (J.C.) \\ 2 Department of Biological and Environmental Sciences, College of Arts and Sciences, Qatar University, \\ Doha, Qatar; benhamadou@qu.edu.qa \\ 3 Battelle UK Ltd., 29 Springfield Lyons Approach, Chelmsford, Essex CM2 5LB, UK; \\ correia.ana10@gmail.com \\ 4 CIMA, Centro de Investigação Marinha e Ambiental, Campus de Gambelas, 8005-139 Faro, Portugal; \\ lchichar@ualg.pt \\ * Correspondence: rgoncalves@ualg.pt; Tel.: +351-289-800-051
}

Academic Editor: Maria Angeles Esteban

Received: 12 September 2017; Accepted: 19 October 2017; Published: 26 October 2017

\begin{abstract}
This work aims to undertake a preliminary characterization of winter fish assemblages in the salt marsh areas of Guadiana lower estuary (South-East Portugal) and discusses the potential risks of habitat dominance by a non-indigenous species (NIS). To this effect, six field campaigns were carried out in four sampling sites during winter season targeting the collection of fish species. A total of 48 samples were collected. Individuals from seven different taxa (marine and estuarine) were collected, although the assemblage was dominated by two estuarine species-the native Pomatoschistus sp. (goby) and the NIS Fundulus heteroclitus (mummichog). Goby was the most abundant taxa in the majority of salt marsh habitats, except for one specific, marsh pool, where extreme environmental conditions were registered, namely high temperature and salinity. Such conditions may have boosted the intrusion of mummichog in this area. This species is well adapted to a wide range of abiotic factors enabling them to colonize habitats where no predators inhabit. Impacts of mummichog introduction in the Guadiana salt marsh area are still unpredictable since this is the first time they have been recorded in such high density. Nevertheless, in scenarios of increased anthropogenic pressure and, consequently, habitat degradation, there is a potential risk of mummichog spreading to other habitats and therefore competing for space and food resources with native species.
\end{abstract}

Keywords: Pomatoschistus sp.; Fundulus heteroclitus; temperature; salinity; anthropogenic pressures; habitat degradation

\section{Introduction}

Worldwide, estuarine areas and their associated salt marsh habitats are described as highly productive and valuable aquatic ecosystems [1]. Due to high levels of primary production, large reserves of organic matter and habitat diversity, these areas are considered biochemical hotspots that offer optimal conditions for numerous birds and aquatic species [2]. These systems provide potential advantages for the growth and survival of young fish, namely high prey availability and refuge from 
predators [1] and, consequently, support the offshore stocks of economically valuable species $[3,4]$. The Guadiana estuary is no exception to this general observation since it provides an exceptionally suitable environment for fish spawning, breeding, feeding, and growth not only for estuarine but also economically important marine species, such as sardine Sardina pilchardus, seabream Diplodus sp., and sole Solea spp. [5,6]. In particular, the sardine is a small pelagic fish of great socio-economic importance for Portugal. Fluctuations in their productivity may cause serious issues for fisheries management and policies in the region [7]. Since winter is the main spawning season of sardine in the study area [8], sampling campaigns for this preliminary study were carried out between January and February. Tidal shifts in fish assemblages have been reported by several authors [9-11] and, therefore, fish were sampled in both tidal stages.

Over the years, estuarine and coastal areas became increasingly affected by anthropogenic activities such as urbanization, industrialization, and tourism [12]. Also, these ecosystems are facing impacts of climatic changes [13]. Such anthropogenic and natural pressures exert a great influence on several environmental factors including temperature, salinity, and macronutrients concentration which in turn will disturb fish. They respond to environmental changes by changing their numbers and/or distributional range, in particular, larvae and juvenile fish which are highly susceptible to environmental fluctuations [14].

The completion of the Alqueva dam located $150 \mathrm{~km}$ from the Guadiana River mouth promoted a reduction in freshwater inflow leading to the degradation of salt marsh vegetation in the lower Guadiana estuary [15]. Moreover, climate change scenarios predict an increase in temperature, length, and frequency of dry periods for this region [13]. Predicted lower precipitation will potentiate retention of river waters and sediments by upstream dams and consequently the degradation of water quality and lack of sediment for plant accretion on salt marsh areas of the lower Guadiana estuary.

The resulting degradation observed in salt marsh habitats per se are a threat to associated fish species, but also increase the risk of invasion by exotic opportunistic species [16]. Invasions are also facilitated by altered environmental conditions. Environmental changes encourage the establishment of non-indigenous species (NIS) which may become potential competitors for native species [17]. In the Guadiana estuary, a community shift has already been documented, including plankton and fish $[15,18,19]$. In addition, the first occurrences of several marine invasive species have also been recorded, with potentially detrimental effects on native biota [13]. In 2008, the invasive Blackfordia virginica (cnidarian) and Palaemon macrodactylus (caridean shrimp) were first observed within the Guadiana estuary [17]. For both species, there is the potential competition for space and resources with native fish such as Sardina pilchardus, Engraulis encrasicolus, Pomatoschistus sp., Solea sp., Diplodus sp., Syngnathus sp. Although the sources of introduction for B. virginica and P. macrodactylus to the Guadiana Estuary remain unknown, previous research has shown that reduction of variability of river flow in estuaries has facilitated the establishment of NIS species [20].

Mummichog is a native species and a dominant faunal component of salt marshes in the Atlantic coast of the United States and Canada [21]. It is described as an opportunistic species due to its high tolerance to extreme and highly variable environmental conditions, namely high salinity and a wide range of temperature [22] which makes mummichog a potential candidate as an invasive species. It has reportedly been introduced to Hawaii, and from there to the Philippines, in the early 20th century [23]. Later, in the 1970s, mummichog arrived in the southwestern Iberian Peninsula apparently due to cross-contamination of ballast water of ships coming from the United States [24]. Occurrences of the species remain poorly documented in the Guadiana [5,6]. There are doubts as to the outcomes of introductions but for now there are no records of native species disappearance where mummichog has been introduced [25].

The objectives of this work are: (a) to characterize winter fish communities in salt marsh areas of Guadiana estuary and their occurrence variability according to tide regime; (b) to investigate the effect of environmental factors on fish species distribution; and (c) to discuss the potential risks of habitat dominance by mummichog, an NIS species. 


\section{Results}

\subsection{Composition of Fish Communities}

A total of 2550 individuals from seven different families were collected from Guadiana estuary salt marshes. Among these, four were estuarine residents (goby, Pomatochistus sp.; mummichog, Fundulus heteroclitus; sand smelt, Atherina sp.; and pipefish, Syngnathus sp.). One species was marine seasonal (sardine, Sardina pilchardus), the other two were marine juveniles (seabream, Diplodus sp. and sole, Solea spp.). Catches were primarily dominated by the estuarine resident goby and secondarily by mummichog, which collectively made up more than $99 \%$ of the total catch.

Marine species were caught at larval stages, except the sole that was also caught in the juvenile stage. The estuarine resident pipefish was caught at the juvenile stage, goby at both larvae and juvenile and mummichog at all stages (from egg to adult). The majority of the captured gobies were juveniles $(87 \%)$ and only $13 \%$ were larvae. Mummichog catches were dominated by larvae (91\%) with only $9 \%$ of juveniles (Table 1, Figure 1).

Table 1. List of captured fish species during the study period in the lower Guadiana estuary salt marsh areas. N: total number; F (\%): frequency; \% of larvae; \% of juveniles; Mean size (mm); Size range (mm); Spatial occupancy: MC "main channel", PIC "principal intertidal creek", SIC "secondary intertidal creek" and MP "marsh pool".

\begin{tabular}{cccccccc}
\hline Species & $\mathbf{N}$ & $\mathbf{F} \mathbf{( \% )}$ & $\begin{array}{c}\text { Larvae } \\
\mathbf{( \% )}\end{array}$ & $\begin{array}{c}\text { Juveniles } \\
\mathbf{( \% )}\end{array}$ & $\begin{array}{c}\text { Mean Size } \\
(\mathbf{m m})\end{array}$ & $\begin{array}{c}\text { Size Range } \\
(\mathbf{m m})\end{array}$ & $\begin{array}{c}\text { Spatial } \\
\text { Occupancy }\end{array}$ \\
\hline Atherina sp. & 1 & 0.04 & - & 100.0 & 36.0 & - & MC \\
Diplodus sp. & 1 & 0.04 & 100.0 & - & 16.0 & - & PIC \\
Fundulus heteroclitus & 479 & 18.93 & 90.6 & 9.4 & 12.1 & $1.6-52.0$ & MP \\
Pomatoschistus sp. & 2043 & 80.75 & 13.0 & 87.0 & 27.1 & $7.0-47.0$ & MC, PIC, SIC, MP \\
Sardina pilchardus & 2 & 0.08 & 100.0 & - & 27.0 & $26.0-28.0$ & MC, SIC \\
Solea spp. & 3 & 0.12 & 66.7 & 33.3 & 13.2 & $6.5-26.0$ & MC \\
Syngnathus sp. & 1 & 0.04 & - & 100.0 & 92.0 & - & MP \\
\hline
\end{tabular}
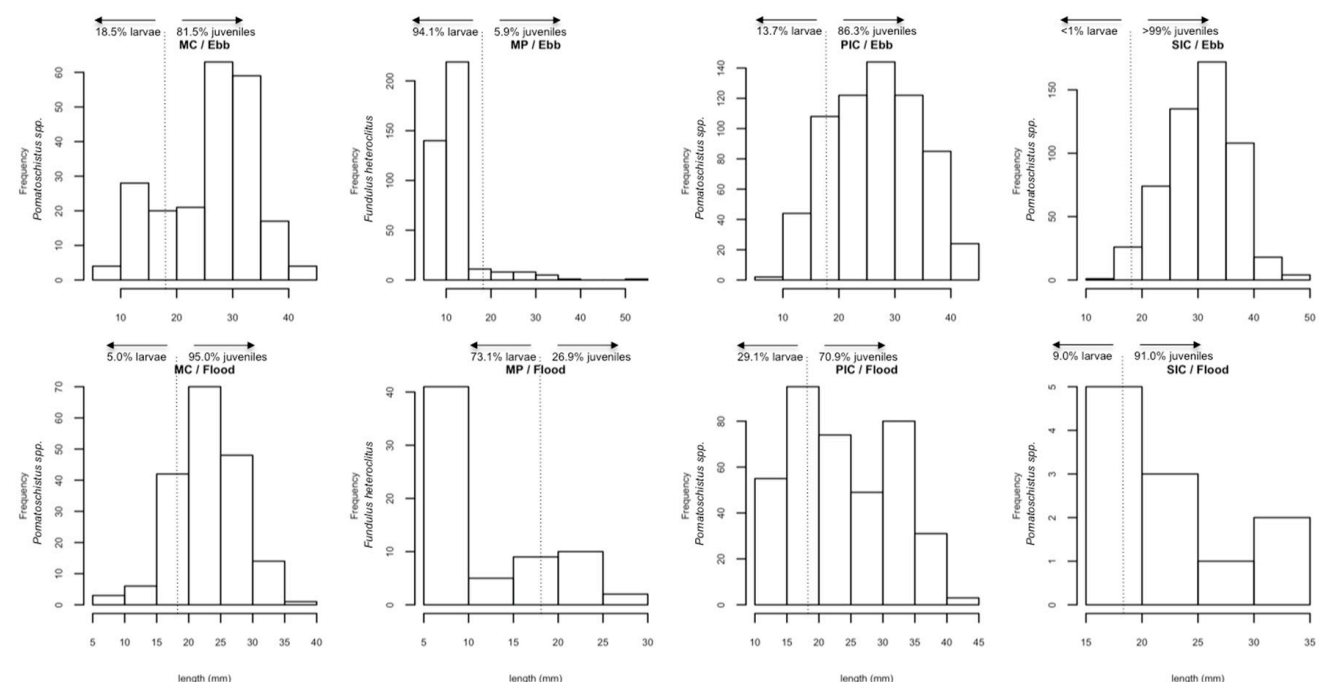

Figure 1. Size and frequency distributions of the two most abundant species per site and tide. Dotted vertical line indicates length at metamorphosis of each species (Pomatoschistus sp.: $17 \mathrm{~mm}$; Fundulus heteroclitus: $18 \mathrm{~mm}$ ).

\subsection{Fish Distribution among Habitats}

Overall, fish density was always higher during ebb tide except for Marsh Pool (MP) habitat. Principal Intertidal Creek (PIC) and Secondary Intertidal Creek (SIC) were the habitats with higher 
densities during the ebb tide. However, fish density in SIC abruptly dropped during the flood (Figure 2) and this habitat presented the lowest percentage of fish larvae (Figure 1). The Analysis of Variance (ANOVA) performed with density data indicated that goby distribution varied significantly between habitats nested with the tide (two-way ANOVA: habitat $\times$ tide $p<0.001$, degrees of freedom $(\mathrm{df})=3$, Tables 2 and 3, Figure 2). The largest differences were found between MP and the remaining habitats. Main Channel (MC), PIC, and SIC were heavily used by fish during ebb tide. MC and PIC were the most and SIC the least used habitats during the flood. Gobies were present in all habitats while mummichog was exclusively observed in MP (Figure 2) justifying the extremely low habitat overlap between the two species in both tide stages (Pianka's measure of niche overlap $\left(\mathrm{O}_{p f}\right)=0.0036$ in the ebb tide and $\mathrm{O}_{p f}=0.0107$ in the flood). Moreover, marine species were never observed in MP habitat (Table 1). Sampling week did not affect the density of goby recorded in each habitat (two-way ANOVA: habitat $\times$ week, $p>0.05$ for week factor $(\mathrm{df}=1)$ and habitat $\times$ week interaction $(\mathrm{df}=3)$ ).
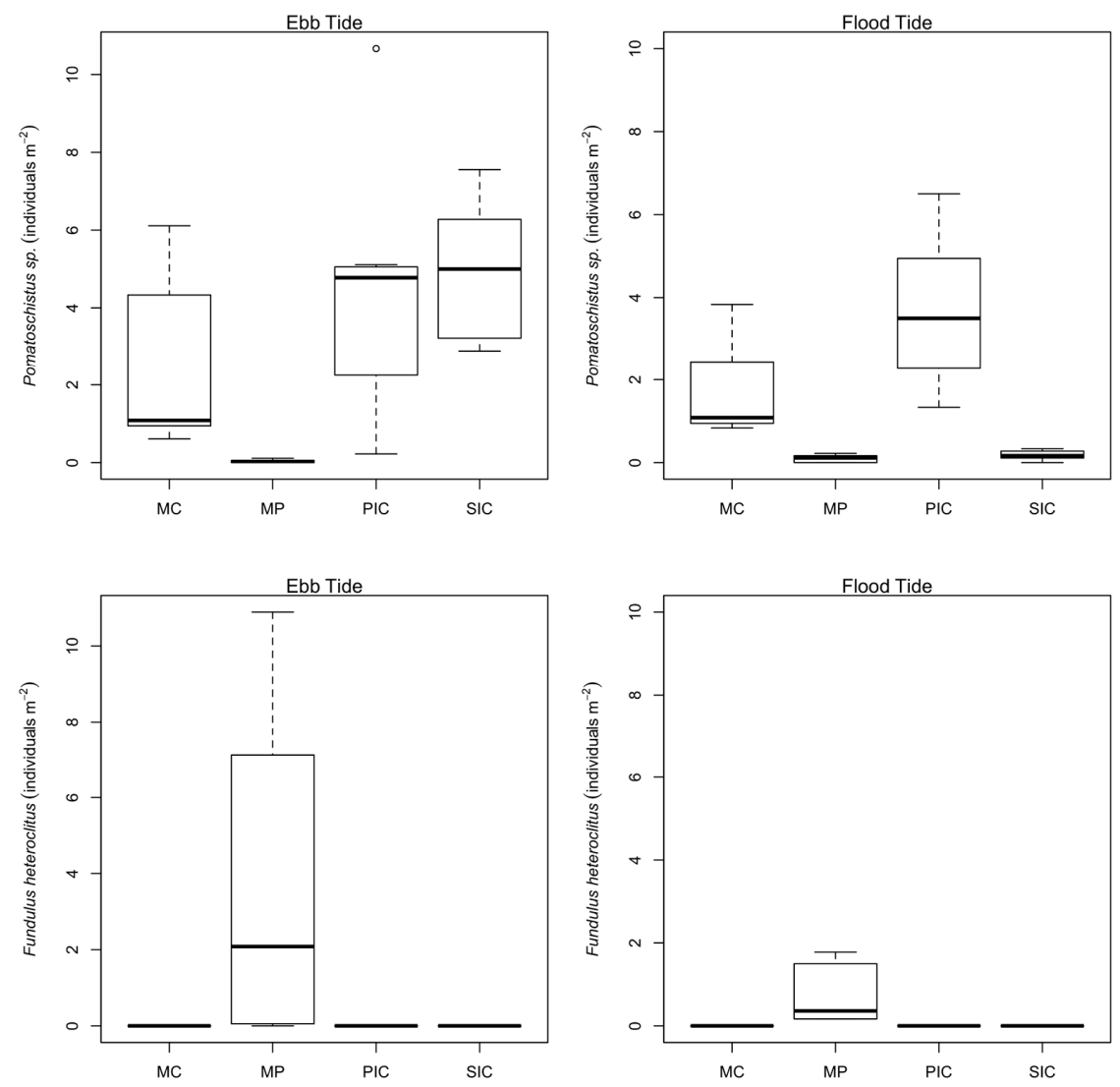

Figure 2. Box plots of fish density (no. individuals $\cdot \mathrm{m}^{-2}$ ) of Pomatoschistus sp. and Fundulus heteroclitus per site and tide captured in the lower Guadiana estuary salt marsh area. The box includes observations from 25 th to the 75 th percentile, the horizontal line within the box represents the median value. Lines outside the box represent the 10th and 90th percentiles.

Table 2. Results of two-way factorial Analysis of Variance (ANOVA) performed on the fish density (no. individuals $\cdot \mathrm{m}^{-2}$, squared root transformed) of the most abundant species (Pomatoschistus sp.) using habitat and tide as fixed factors. Level of significance: ${ }^{*} p<0.001$.

\begin{tabular}{cccc}
\hline & Degrees of Freedom (df) & Mean Square & F Ratio \\
\hline Habitat & 3 & 7.333 & $40.59^{*}$ \\
Tide & 1 & 4.098 & $22.68^{*}$ \\
Habitat $\times$ Tide & 3 & 2.243 & $12.42^{*}$ \\
Error & 40 & 0.181 & \\
\hline
\end{tabular}


Table 3. Results of Tukey (HSD) test for habitat comparisons in each tide state performed on the fish density (no. individuals $\mathrm{m}^{-2}$, squared root transformed) of the most abundant species (Pomatoschistus sp.). Levels of significance: ns, not significant; ${ }^{* * *} p<0.001 ;{ }^{* *} p<0.01 ;{ }^{*} p<0.05$.

\begin{tabular}{ccc}
\hline Tide & Habitat & $p$ Value \\
\hline Ebb & MC vs. PIC & $0.009^{* *}$ \\
& MP vs. PIC & $0.000^{* * *}$ \\
& SIC vs. PIC & $0.999 \mathrm{~ns}$ \\
& MP vs. MC & $0.000^{* * *}$ \\
& SIC vs. MC & $0.041^{*}$ \\
Flood & SIC vs. MP & $0.000^{* * *}$ \\
& MC vs. PIC & $0.236 \mathrm{~ns}$ \\
& MP vs. PIC & $0.000^{* * *}$ \\
& SIC vs. PIC & $0.000^{* * *}$ \\
& MP vs. MC & $0.005^{* *}$ \\
& SIC vs. MC & $0.020^{*}$ \\
& SIC vs. MP & $0.999 \mathrm{~ns}$ \\
\hline
\end{tabular}

\subsection{Environmental Parameters}

Maximum water temperature was recorded in the MP habitat during the ebb $\left(17.1^{\circ} \mathrm{C}\right)$ and minimum in the PIC during the flood $\left(13.3^{\circ} \mathrm{C}\right)$. The temperature ranges within $\mathrm{MC}, \mathrm{PIC}$, and SIC were very similar. The patterns of temperature variation among sites were analogous in both tidal stages with a slight decrease in temperature observed during the flood (Figure 3). The relationship between environmental factors and the density of the two dominant species (goby and mummichog) were explored using the Spearman's rank correlation. A more complex analysis-Generalized Additive Models (GAM) - was not possible due to the lack of robustness of collected data. Residuals normal distribution assumption was violated even after data transformation. There was a negative correlation between temperature and goby larvae density, and a positive correlation between temperature and mummichog (larvae and juveniles) density (Table 4).
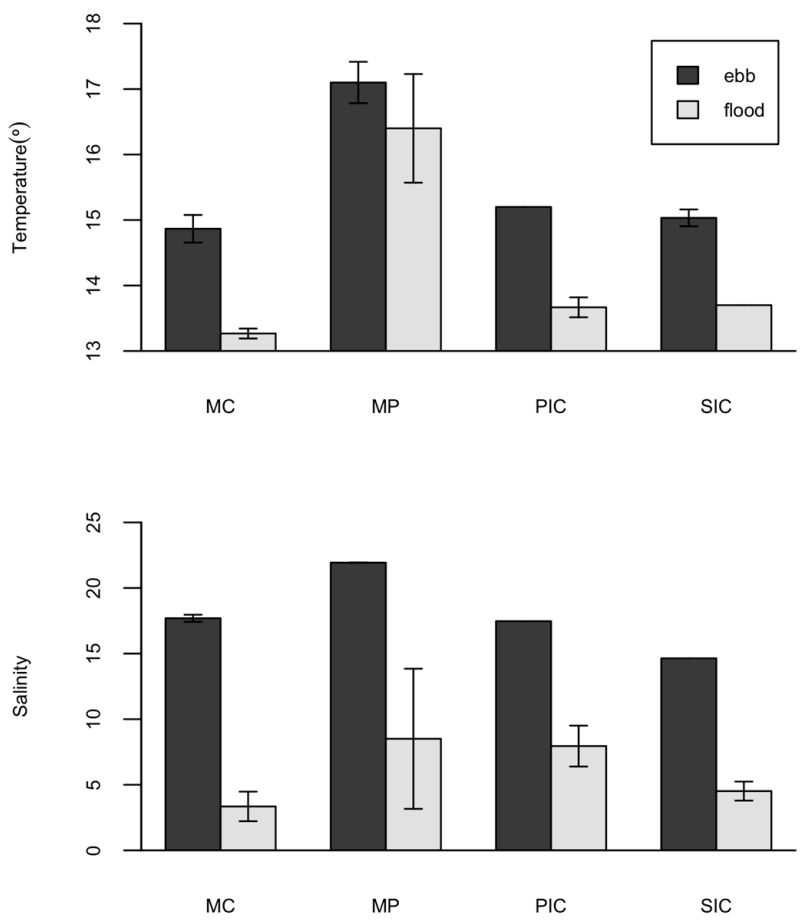

Figure 3. Spatial and tidal variation of temperature and salinity measured at each sampling site during the study period in the lower Guadiana estuary salt marsh areas. 
Table 4. Results of Spearman correlation indices (rho) between larvae and juvenile densities of the two most abundant species and the environmental variables. Level of significance $*<<0.05$.

\begin{tabular}{ccccc}
\hline & \multicolumn{2}{c}{ Density of Pomatoschistus sp. } & \multicolumn{2}{c}{ Density of Fundulus heteroclitus } \\
\hline & Juveniles & Larvae & Juveniles & Larvae \\
\hline Temperature $\left(^{\circ}\right)$ & -0.244 & $-0.332^{*}$ & $0.564^{*}$ & $0.517^{*}$ \\
Salinity & -0.105 & -0.143 & 0.060 & 0.211 \\
Dissolved Oxygen $\left(\mathrm{mg} \cdot \mathrm{L}^{-1}\right)$ & -0.208 & -0.133 & -0.084 & -0.137 \\
Cha $\left(\mathrm{mg} \cdot \mathrm{L}^{-1}\right)$ & 0.109 & 0.214 & 0.160 & 0.031 \\
Ammonium $\left(\mathrm{mg} \cdot \mathrm{L}^{-1}\right)$ & 0.017 & -0.103 & 0.048 & -0.131 \\
Nitrate $\left(\mathrm{mg} \cdot \mathrm{L}^{-1}\right)$ & $0.467^{*}$ & $0.645^{*}$ & $-0.508^{*}$ & $-0.703^{*}$ \\
Nitrite $\left(\mathrm{mg} \cdot \mathrm{L}^{-1}\right)$ & 0.190 & $0.493^{*}$ & -0.185 & -0.213 \\
Phosphate $\left(\mathrm{mg} \cdot \mathrm{L}^{-1}\right)$ & $0.489^{*}$ & $0.361^{* *}$ & $-0.310^{*}$ & -0.250 \\
\hline
\end{tabular}

Salinity ranged between 3 and 22 with significantly higher values during ebb. A peak of salinity, as for temperature, was also registered in the MP habitat in both tides (Figure 3). There was no correlation between salinity and fish density (Table 4). Dissolved oxygen (DO) concentration ranged between 5.6 and $9.3 \mathrm{mg} \cdot \mathrm{L}^{-1}$ with higher values during the flood. The highest values $\left(2.53 \mathrm{mg} \cdot \mathrm{L}^{-1}\right)$ of chlorophyll $a(\mathrm{Ch} a)$ were registered in the MC habitat during ebb tide and the lowest values $\left(1.10 \mathrm{mg} \cdot \mathrm{L}^{-1}\right)$ in SIC also during ebb tide. There was no correlation between fish density and both $\mathrm{DO}$ or Cha. Maximum of all nutrients concentration occurred in the PIC and minimum in the MP habitat except for nitrite (Figure 4). Nitrate concentration was extremely low in the MP during ebb and flood $\left(0.065 \pm 0.025\right.$ and $0.050 \pm 0.022 \mathrm{mg} \cdot \mathrm{L}^{-1}$, respectively). Goby juvenile's density was positively correlated with nitrate and phosphate and goby larvae with nitrite, nitrate, and phosphate. There was a negative correlation between mummichog (larvae and juvenile) density and nitrate. Mummichog juvenile density was negatively correlated also with phosphate (Table 4).
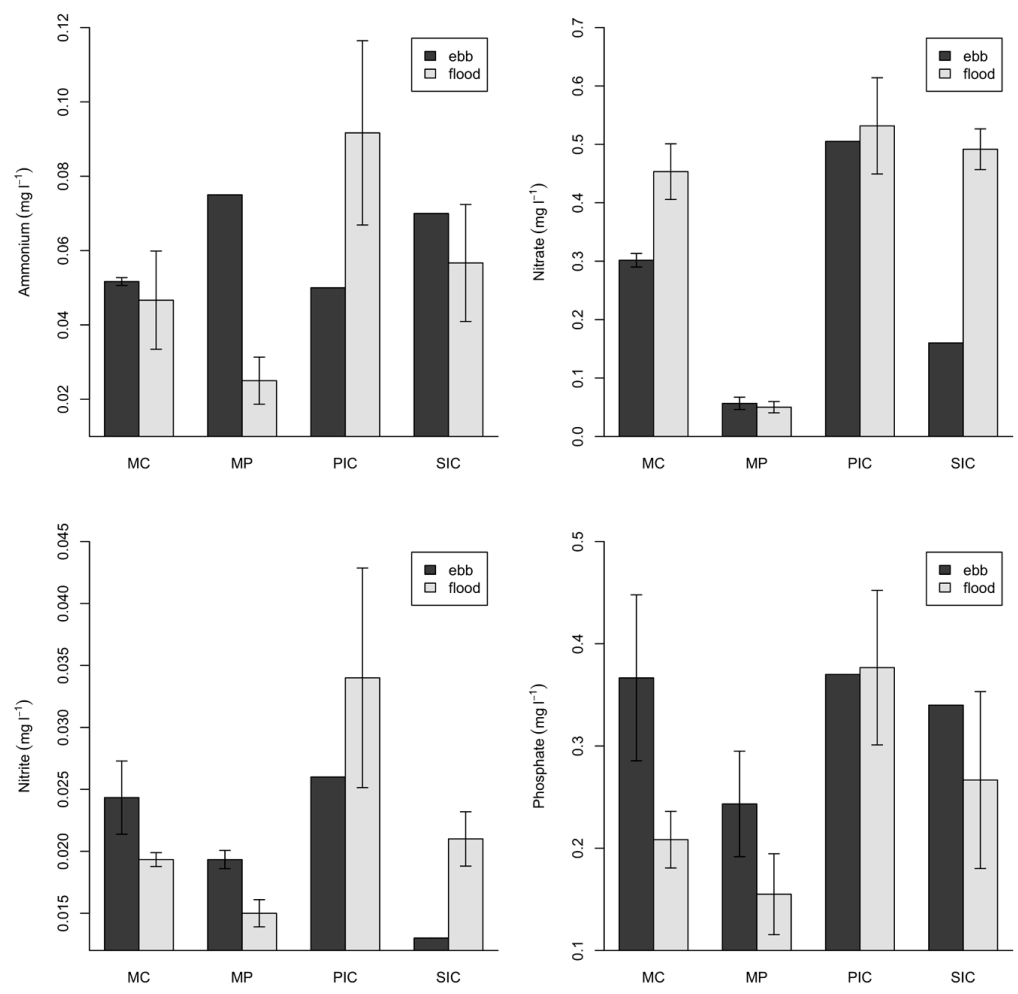

Figure 4. Spatial and tidal variation of macronutrients concentration (ammonium, nitrite, nitrate and phosphate) measured at each sampling site during the study period in the lower Guadiana estuary salt marsh areas. 


\section{Discussion}

For the first time, the occurrence of mummichog in such high densities is reported in South Portugal and their potential risk for native species discussed. The present study was performed during winter months and thus, fish density and diversity registered herein were relatively low, as expected for this season and region [5,6] and in other salt marsh areas of Portugal [11], North Europe [26,27] and United States [28,29]. All the seven fish genera captured had been previously observed in the study area [5,6] although mummichog in very low densities [5]. Goby and mummichog, two estuarine residents, the first being native and the latter NIS, were the two dominant species. Overall, the degree of habitat overlap between these two species was very low in both tidal stages, as shown by the low values of Pianka's index. This indicates that the two species occupy different habitats with the NIS mummichog being exclusively present in an isolated habitat (MP). Gobies are among the most abundant genera all over European salt marshes $[6,27,30]$, and are particularly successful in temperate estuarine environments [31]. There are records of mummichog in southwest Spain [22]; however, occurrences of mummichog in Portugal are poorly documented. Veiga recorded their presence between 2001 and 2002 in Guadiana salt marsh subtidal creeks but as low as one individual in the total catch [5].

In the salt marshes, marine species were mainly caught at larval stages, while estuarine residents occurred at both larval and juvenile stages. These results indicate that marine species use salt marshes mainly as a nursery area while estuarine species depend on salt marshes during their entire life cycle [32].

Tides affected goby density in MC, PIC and SIC habitats in a similar way, with higher densities registered during ebb. The authors of [33] developed a hydrodynamic model for Guadiana estuary. Results indicate water surface velocities of $5.3 \mathrm{cms}^{-1}$ (SIC) and $12.9 \mathrm{cms}^{-1}$ (MC) during the ebb and $8.8 \mathrm{cms}^{-1}$ (SIC) and $15.8 \mathrm{cms}^{-1}$ (MC) during the flood. Lower velocities in the ebb may facilitate fish spread throughout the sampled salt marsh habitats especially for the youngest. In fact, changes in fish density according to the tidal stages occur due to the movement of fish from permanently inundated areas towards the inundated intertidal areas with the flood tide [11]. Differences in fish assemblages may also be influenced by marsh plain availability in the proximity to each sampling site. However, this does not seem to be the case if marsh plain area and vegetation type is very similar among habitats. It is worth mentioning that the presence of estuarine fish larvae in all the sampled sites indicate an active habitat selection capacity from an early life stage. Our data do not support the same assumption for marine species due to the small number of marine larvae caught. Nevertheless, previous studies performed in some of the fish genera caught during this investigation reported larvae swimming speeds (Table 5) in the range of simulated current velocities by [33]. It should be noted that although the model developed by [33] was calibrated with data recorded after the construction of the Alqueva dam, it is not guaranteed that similar velocities occurred during samplings. Results show that despite inter- and subtidal salt marsh creeks not being continuously available habitats, they play a major role in both estuarine and marine species, and for both larvae and juvenile fish.

Table 5. Critical swimming speeds (Ucrit) of three marine fish larvae species.

\begin{tabular}{cccc}
\hline Species & Ucrit Range $\left(\mathbf{c m s}^{-\mathbf{1}}\right)$ & Size Range $(\mathbf{m m})$ & Reference \\
\hline Atherina presbyter & $3.6-18.7$ & $6.6-21.0$ & {$[34]$} \\
Solea senegalensis & $0.0-5.0$ & $3.5-7.5$ & {$[35]$} \\
Sardina pilchardus & $1.6-9.5$ & $7.9-23.4$ & {$[36]$} \\
\hline
\end{tabular}

MP was the most dissimilar habitat, both in terms of fish composition and environmental parameters, presenting the highest temperatures and salinities and the lowest macronutrients concentration, namely nitrates and phosphates. Extreme abiotic conditions registered were caused by the lack of water renewal since the MP is only partially flushed during high tides. Mummichog inhabits a wide range of salinities but prefers the most saline sites, usually above 25 [22,25,37]. They present a 
great euryhaline range, covering 0 to 128 [38]. Altogether, with their wide thermic acclimation range, this species is able to colonize new habitats with great success [25]. MP was also the habitat with the lowest concentration of macronutrients, in particular phosphates and nitrates. According to [39], phosphate and nitrate concentrations registered at MP indicate a low impacted area, in comparison to the other three habitats (SIC, PIC, MC) that presented typical values of moderate to high eutrophic sites. Nutrient enrichment is known to stimulate primary production causing a bottom-up enrichment of the food web, fostering increased fish biomass and body size [39]. Particularly, nitrogen and phosphorus enrichment stimulates benthic algae [40], which in turn stimulates infauna and epibenthic invertebrates [41]. Benthic algae, infauna and epibenthic invertebrates all serve as food resources for most estuarine dependent fish species [39]. However, a nutrient over-enrichment can have deleterious consequences, namely a decrease in dissolved oxygen leading to a reduction in fish growth rates [39]. Fish such as gobies, that make use of eutrophic environments, are not likely to stay long enough to experience the negative effect of hypoxia on their growth. As observed by [42], they invade the salt marshes through tidal creeks, forage there for up to a few hours and swim back at the ebb. Such habitats are available for a limited time dependent on tides. Instead, for short periods, they colonize salt marsh creeks and main channel edge and benefit from the high availability of food which in turn are probably influenced by the high concentration of macronutrients [41]. Accounting for the lower concentration of macronutrients observed in MP, also a lower stimulation of primary production and consequently less food availability may be expected for this habitat which might thus explain the lower occurrence of gobies.

Gobies are described as opportunistic carnivores feeding on prey according to its availability. Most important prey items in their diet are polychaetes, mysids, isopods and decapods [31]. Mummichog is also an opportunistic species but omnivore. Their diet is mainly based on amphipods, isopods, and snails [39]. There is some overlap on feeding preferences of both species but mummichog is highly flexible, easily adapting to a more herbivory diet (plant tissues) in case of animal prey reduction [39].

Mummichog growth is quite fast, being able to reproduce within the first year of life. Their eggs are resistant to desiccation, their development is fast and thus, the post-hatched larvae start with great advantages due to their size [37]. Such characteristics provide this fish species an opportunistic life-history strategy effectively adapting to habitats with extreme environmental conditions as observed in MP. Although goby is described as a widespread species, relatively tolerant to fluctuations in environmental conditions [43], the establishment of mummichog in MP suggests that this habitat was not attractive to goby as the remain three sampled habitats [22]. In fact, the majority of the studies observed that mummichog is occupying extreme habitats (empty niches) not previously used by native fish species $[25,37,44]$ as it seems to be the current scenario in Guadiana salt marshes. This accounts for the low degree of habitat overlap (Pianka's index) between gobies and mummichog. However, a species with such an expansion capacity, along with its productivity, must have a great influence on the local fish populations.

At least 35 NIS fish species have been introduced into the Iberian Peninsula in the last century and, although not all of them prospered, most are now widespread in this area especially linked to degraded environments [45]. Extensive urban development has occurred in the Guadiana River basin over the past century: the consequent reduction in river flow contributed to decreases in water quality [46]. The presence of mummichog does not necessarily imply that a successful invasion has occurred. We did, however, find specimens over a wide range of sizes $(1.6-52.0 \mathrm{~mm})$ and development stages that imply local reproduction. As such, mummichog must be classified as an NIS species in Guadiana salt marsh area, i.e., a species introduced outside its natural distribution that might survive and subsequently reproduce. Not all NIS species turn into invasive species, defined as species with the potential to cause native species extinction, modify ecosystem processes and act as disease vectors [47]. However, some species out of their natural habitats lose their natural predators or control 
agents. As a result, they are able to increase to levels which are potentially detrimental to the native environment [47].

Mummichog establishment was recorded in an isolated and low attractive area for native species due to extreme environmental conditions registered. However, similar to what is happening in areas relatively close in South Spain, Guadiana Estuary salt marsh habitats are facing the threat of an expansion of this NIS species to close areas of great value for native species. More sampling effort at reference and impact sites in the study area will be needed to verify the potential effects of mummichog on native communities. Various measures are being taken to improve management of water bodies in the Guadiana river basin under the Water Framework Directive in conjunction with the new European Marine Strategy Framework Directive. The new strategic plan which came into force in 2016 and will be in action until 2021 provides for several measures that will potentially mitigate the risk of mummichog expansion, among them: (a) reduce or eliminate discharges of pollutants; (b) define and implement ecological flows; and (c) increase monitoring and supervising plans [48]. The authors recommend that future monitoring studies should be carried out in the study area to evaluate the effectiveness of the new measures implemented in control not only of this but other NIS species.

\section{Materials and Methods}

\subsection{Sampling and Field Methodology}

Larval and juvenile fishes were collected between January and February of 2013 at four sites in the Natural Reserve of Castro Marim and Vila Real de Santo António (South-East Portugal) salt marsh area. The first sampling site, Main Channel (MC, $37^{\circ} 13^{\prime} 59^{\prime \prime} \mathrm{N}, 7^{\circ} 25^{\prime} 8^{\prime \prime} \mathrm{W}$ ), was set on the edge of the main course of the Guadiana estuary; the second, Primary Intertidal Creek (PIC, $37^{\circ} 14^{\prime} 2^{\prime \prime} \mathrm{N}$, $7^{\circ} 25^{\prime} 23^{\prime \prime} \mathrm{W}$ ), a small creek directly connected to the main channel; the third, Secondary Intertidal Creek (SIC, $37^{\circ} 13^{\prime} 16^{\prime \prime} \mathrm{N}, 7^{\circ} 25^{\prime} 52^{\prime \prime} \mathrm{W}$ ), also a small creek with secondary connection to the main channel; and the fourth, Marsh Pool (MP, $37^{\circ} 13^{\prime} 52^{\prime \prime}$ N, $7^{\circ} 25^{\prime} 44^{\prime \prime} \mathrm{W}$ ), an area permanently inundated due to the partially obstruction of water flow by a small dyke (Figure 5). A preliminary survey was performed in order to evaluate the adequacy of sampling points and methodologies to the characteristics of the habitats. Accessibility and representativeness were the main factors considered for the selection of sampling sites.

A total of six diurnal field campaigns were carried out weekly - three at the end of ebb and the other three at the end of flood tides. Samples were collected weekly at each of the four sites. In each week at each site, two samples were collected at the end of ebb or flood tide. This gave a total of 48 samples ( $n=12$ samples per site; $n=24$ samples per tide; $n=6$ samples per site $\times$ tide). Fishes were captured with a seine net ( $1 \mathrm{~mm}$ net size, $5 \mathrm{~m}$ length and $0.5 \mathrm{~m}$ height). Capture procedure consisted of encircling an area of approximately $18 \mathrm{~m}^{2}$ near the edge of the main channel, intertidal creeks and marsh pool. One of the operators stood on a fixed point holding one of the extremities of the net, while a second operator dragged the net manually in a circle, meeting the first operator at the fixed point. When the two operators meet each other, the net was pulled close to the shore. The bottom of the seine net was equipped with weights in order to guarantee that it remained in permanent and direct contact with the bottom. Each seine took approximately $10 \mathrm{~min}$ and was performed twice at each point per sampling week. Collected samples were immediately preserved in buffered formaldehyde solution ( $4 \%$ final concentration) for further analysis. Animal handling was performed following the European Directive 2010/63/EU of European Parliament and of the Council of European Union on the protection of animals used for scientific purposes. Additionally, physical-chemical parameters (temperature, salinity, dissolved oxygen, and $\mathrm{pH}$ ) were recorded at each station with a YSI Model 85 multiparameter system probe (YSI Incorporated, Yellow Springs, OH, USA) immersed approximately 10-20 cm from the water surface. Finally, for each point, water samples were collected from the surface for the analysis of dissolved inorganic macronutrients (ammonium, $\mathrm{NH}_{4}{ }^{+}$; nitrate, $\mathrm{NO}_{3}{ }^{-}$; nitrite, $\mathrm{NO}_{2}{ }^{-}$; and 
phosphate, $\mathrm{PO}_{4}{ }^{3-}$ ) and chlorophyll $a$. Samples were immediately stored in $330 \mathrm{~mL}$ containers in the dark and at low temperature, until further processing.

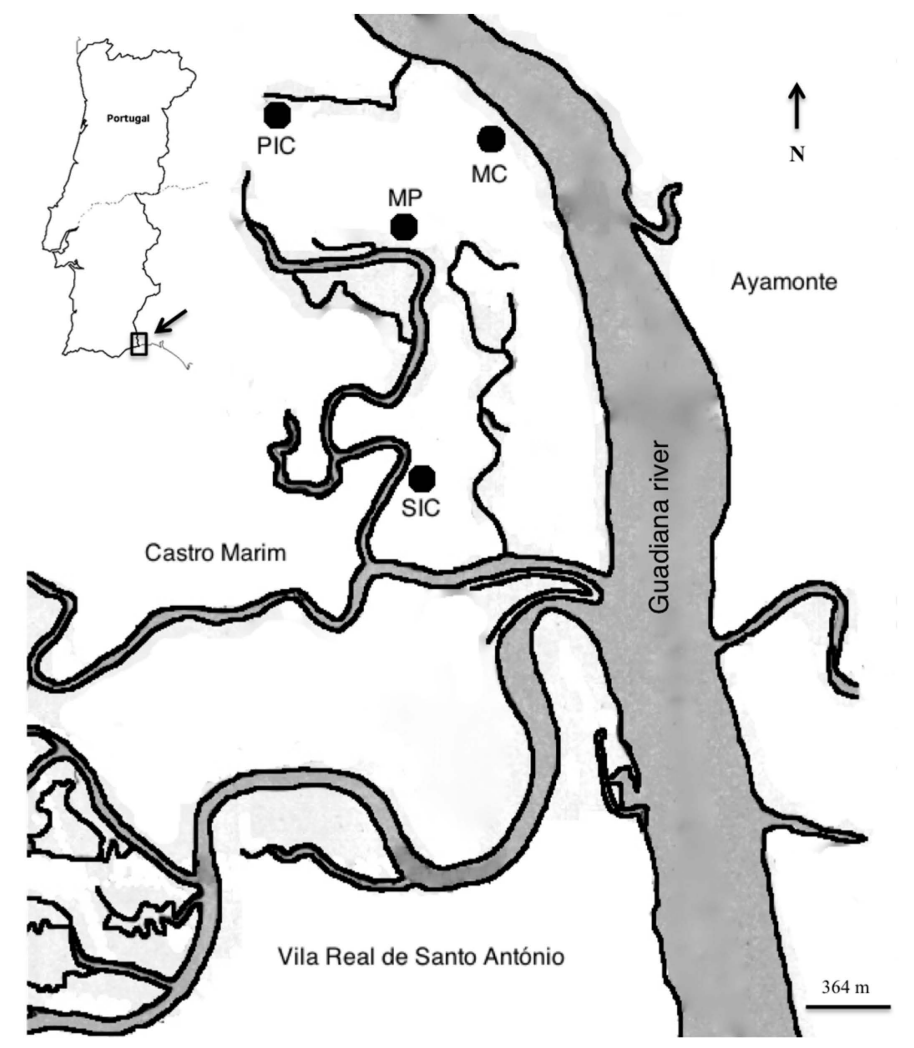

Figure 5. Geographical context of the Natural Reserve of Castro Marim and Vila Real de Santo António in Portugal and sampling sites localization in the Natural Reserve salt marsh area.

\subsection{Laboratory Analysis}

In the laboratory, preserved marine juvenile fishes were measured for total length (precision $\pm 1.0 \mathrm{~mm}$ ) and identified according to [49,50]. Fish larvae were measured for total length (precision $\pm 0.1 \mathrm{~mm}$ ) and identified according to [51,52] under a Leica S8 APO stereomicroscope (Leica Microsystems Wetzlar GmbH, Wetzlar, Germany). Identified fish species were classified into ecological guilds, according to their biology and behavior reported in the literature (Table 6).

Table 6. Ecological guild definition of captured fish species during the study period in the lower Guadiana estuary salt marsh areas

\begin{tabular}{|c|c|c|}
\hline Ecological Guild & Definition & Reference \\
\hline Estuarine resident & Spend their entire lives in the estuary & [53] \\
\hline Marine seasonal & Have regular seasonal visits to the estuary, mainly as adults & [53] \\
\hline Marine juvenile & $\begin{array}{l}\text { Use the estuary as nursery ground, usually spawning and spending } \\
\text { much of their adult life at sea with seasonal visits to the estuary }\end{array}$ & [53] \\
\hline
\end{tabular}

Chlorophyll $a$ concentration was determined by filtering water samples through $0.7 \mu \mathrm{m}$ pore Whatman GF/F filters (GE Healthcare Life Sciences, Buckinghamshire, UK) without exceeding vacuum pressures of $100 \mathrm{mmHg}$. The filters were kept frozen until fluorimetric analysis using the Fluorimeter 10 AU (Turner Designs, Sunnyvale, CA, USA). Finally, dissolved inorganic macronutrients concentrations were determined according to a spectrophotometric method using Spectroquant cell 
test photometric kits (Merck Millipore, Damstadt, Germany) and the Spectroquant Nova 60 photometer (Merck Millipore).

\subsection{Data Analysis}

Two-way factorial Analysis of Variance was used to test for differences in fish densities of the most abundant species (Pomatoschistus sp.) among sampling sites and tide stages. Both independent variables were considered as fixed factors. Fish density data was transformed to square root in order to reduce the heteroscedasticity of the data. Tukey's HSD test was used for post hoc comparisons when significant differences were detected $(p<0.01)$. The Spearman correlation coefficient was used to explore patterns of association among the environmental variables and the density of larvae and juveniles of the two most abundant species (Pomatoschistus sp. and Fundulus heteroclitus). The habitat niche overlap between Pomatoschistus sp. and Fundulus heteroclitus was evaluated through Pianka's index [54], and applied to the mean density (no. individuals $\mathrm{m}^{-2}$ ) of each species in each habitat sampled. Pianka's formula is $O_{p f}=\sum P_{i p} P_{i f} \div \sqrt{ } \sum P_{i p}^{2} \sum P_{i f}^{2}$, where $\mathrm{O}_{p f}$ is Pianka's measure of niche overlap between Pomatoschistus sp. and Fundulus heteroclitus; $P_{i p}$ is the proportion of the resource $i$ out of the total resources used by Pomatoschistus sp.; $P_{\text {if }}$ is the proportion of the resource $i$ out of the total resources used by Fundulus heteroclitus; $i$ could range from 1 to $n$, where $n$ is the total number of habitats considered (in our case $n=4$, the number of sampled habitats). The value of index $O$ could range from 0 (no overlap) to 1 (full overlap). All statistics were applied using the open source software $\mathrm{R}$ version 2.15.1 [55]. Spaa package [56] was applied for Pianka's index calculation.

Acknowledgments: The authors are indebted to Marília Claro, Katarzyna Sroczynska, and Simão Santos, who helped with the field work. We are also grateful to the anonymous reviewers who improved earlier drafts of this manuscript and to Gelmar Bechara for language editing. This work was supported by the FCT (Portuguese Foundation for Science and Technology) through a Ph.D. grant awarded to Renata Gonçalves (SFRH/47985/2008), the European Regional Development Fund (COMPETE program-Operational Competitiveness Program), and by national funds from FCT through project UID/Multi/04326/2013.

Author Contributions: The contribution of each author was the following: Renata Gonçalves was involved in the work planning, field and laboratory work execution, data analysis and writing of the manuscript; Maria Alexandra Teodósio was involved in data analysis and writing of the manuscript by giving scientific and editorial advice; Joana Cruz was involved in laboratory work execution and writing of the manuscript by giving scientific and editorial advice; Ana Dulce Correia was involved in the writing of the manuscript by giving scientific and editorial advice; Radhouane Ben-Hamadou was involved in work planning, data analysis and writing the manuscript by giving scientific and editorial advice; Luís Chícharo was involved in work planning and writing the manuscript by giving scientific and editorial advice.

Conflicts of Interest: The authors declare no conflict of interest. The funding sponsors had no role in the design of the study; in the collection, analyses, or interpretation of data; in the writing of the manuscript, and in the decision to publish the results.

\section{References}

1. Vasconcelos, R.P.; Reis-Santos, P.; Fonseca, V.; Maia, A.; Ruano, M.; França, S.; Vinagre, C.; Costa, M.J.; Cabral, H. Assessing anthropogenic pressures on estuarine fish nurseries along the Portuguese coast: A multi-metric index and conceptual approach. Sci. Total Environ. 2007, 374, 199-215. [CrossRef] [PubMed]

2. Barbier, E.B.; Hacker, S.D.; Kennedy, C.; Koch, E.; Stier, A.C.; Silliman, B.R. The value of estuarine and coastal ecosystem services. Ecol. Monogr. 2011, 81, 169-193. [CrossRef]

3. Beck, M.W.; Heck, K.L.; Able, K.W.; Childers, D.L.; Eggleston, D.B.; Gillanders, B.M.; Halpern, B.; Hays, C.G.; Hoshino, K.; Minello, T.J.; et al. The Identification, Conservation, and Management of Estuarine and Marine Nurseries for Fish and Invertebrates. Bioscience 2001, 51, 633. [CrossRef]

4. Able, K.W. A re-examination of fish estuarine dependence: Evidence for connectivity between estuarine and ocean habitats. Estuar. Coast. Shelf Sci. 2005, 64, 5-17. [CrossRef]

5. Veiga, P.; Vieira, L.; Bexiga, C.; Sa, R.; Erzini, K. Structure and temporal variations of fish assemblages of the Castro Marim salt marsh, southern Portugal. Estuar. Coast. Shelf Sci. 2006, 70, 27-38. [CrossRef] 
6. Gonçalves, R.; Correia, A.D.; Atanasova, N.; Teodósio, M.A.; Ben-Hamadou, R.; Chícharo, L. Environmental factors affecting larval fish community in the salt marsh area of Guadiana estuary (Algarve, Portugal). Sci. Mar. 2015, 79, 25-34. [CrossRef]

7. Santos, A.M.P.; Chícharo, A.; Dos Santos, A.; Moita, T.; Oliveira, P.B.; Peliz, A.; Ré, P. Physical-biological interactions in the life history of small pelagic fish in the Western Iberia Upwelling Ecosystem. Prog. Oceanogr. 2007, 74, 192-209. [CrossRef]

8. Zwolinski, J.; Stratoudakis, Y.; Soares, E. Intraannual variation in the batch fecundity of sardine off Portugal. J. Fish Biol. 2001, 58, 1633-1645. [CrossRef]

9. Sogard, S.M.; Able, K.W. A comparison of eelgrass, sea lettuce macro-algae, and marsh creeks as habitats for epibenthic fishes and decapods. Estuar. Coast. Shelf Sci. 1991, 33, 501-519. [CrossRef]

10. Guest, M.A.; Connolly, R.M.; Loneragan, N.R. Seine nets and beam trawls compared by day and night for sampling fish and crustaceans in shallow seagrass habitat. Fish Res. 2003, 64, 185-196. [CrossRef]

11. Ribeiro, J.; Bentes, L.; Coelho, R.; Gonçalves, J.; Lino, P.; Monteiro, P.; Erzini, K. Seasonal, tidal and diurnal changes in fish assemblages in the Ria Formosa lagoon (Portugal). Estuar. Coast. Shelf Sci. 2006, 67, 461-474. [CrossRef]

12. Cravo, A.; Lopes, B.; Serafim, A.; Company, R.; Barreira, L.; Gomes, T.; Bebianno, M.J. A multibiomarker approach in Mytilus galloprovincialis to assess environmental quality. J. Environ. Monit. 2009, 11, 1673-1686. [CrossRef] [PubMed]

13. IPCC. Climate Change 2007: Synthesis Report. Contribution of Working Groups I, II and III to the Fourth Assessment Report of the Intergovernmental Panel on Climate Change; Core Writing Team, Pachauri, R.K., Reisinger, A., Eds.; IPCC: Geneva, Switzerland, 2007.

14. Cushing, D.H. Plankton production and year-class strength in fish populations: An update of the match/mismatch hypothesis. Adv. Mar. Biol. 1990, 26, 249-293. [CrossRef]

15. Crooks, J.A.; Chang, A.L.; Ruiz, G.M. Aquatic pollution increases the relative success of invasive species. Biol. Invasions 2010, 13, 165-176. [CrossRef]

16. Chícharo, M.A.; Chícharo, L.; Morais, P. Inter-annual differences of ichthyofauna structure of the Guadiana estuary and adjacent coastal area (SE Portugal/SW Spain): Before and after Alqueva dam construction. Estuar. Coast. Shelf Sci. 2006, 70, 39-51. [CrossRef]

17. Chícharo, M.A.; Leitão, T.; Range, P.; Gutierrez, C.; Morales, J.; Morais, P.; Chícharo, L. Alien species in the Guadiana Estuary (SE-Portugal/SW-Spain): Blackfordia virginica (Cnidaria, Hydrozoa) and Palaemon macrodactylus (Crustacea, Decapoda): Potential impacts and mitigation measures. Aquat. Invasions 2009, 4, 501-506. [CrossRef]

18. Faria, A.; Morais, P.; Chícharo, M.A. Ichthyoplankton dynamics in the Guadiana estuary and adjacent coastal area, South-East Portugal. Estuar. Coast. Shelf Sci. 2006, 70, 85-97. [CrossRef]

19. Domingues, R.B.; Sobrino, C.; Galvão, H. Impact of reservoir filling on phytoplankton succession and cyanobacteria blooms in a temperate estuary. Estuar. Coast. Shelf Sci. 2007, 74, 31-43. [CrossRef]

20. Bunn, S.E.; Arthington, A.H. Basic Principles and Ecological Consequences of Altered Flow Regimes for Aquatic Biodiversity. Environ. Manag. 2002, 30, 492-507. [CrossRef]

21. Hagan, S.M.; Brown, S.A.; Able, K.W. Production of mummichog (Fundulus heteroclitus): Response in marshes treated for common reed (Phragmites australis) removal. Wetlands 2007, 27, 54-67. [CrossRef]

22. Fernández-Delgado, C. Life-history patterns of the salt-marsh killifish Fundulus heteroclitus (L.) introduced in the estuary of the guadalquivir river (South West Spain). Estuar. Coast. Shelf Sci. 1989, 29, 573-582. [CrossRef]

23. Froese, R.; Pauly, D. (Eds.) FishBase; World Wide Web Electronic Publication: Kiel, Germany, 2017. Available online: www.fishbase.org (accessed on 11 October 2017).

24. Sierra, J. La aparición del pez momia en el Delta del Ebro amenaza al samaruc valenciano. Las Provincias 2006, 6. (In Spanish)

25. Gutiérrez-Estrada, J.C.; Prenda, J.; Oliva, F.; Fernández-Delgado, C. Distribution and Habitat Preferences of the Introduced Mummichog Fundulus heteroclitus (Linneaus) in South-western Spain. Estuar. Coast. Shelf Sci. 1998, 46, 827-835. [CrossRef]

26. Koutsogiannopoulou, V.; Wilson, J.G. The fish assemblage of the intertidal salt marsh creeks in North Bull Island, Dublin Bay: Seasonal and tidal changes in composition, distribution and abundance. Hydrobiologia 2007, 588, 213-224. [CrossRef] 
27. Green, B.C.; Smith, D.J.; Earley, S.E.; Hepburn, L.J.; Underwood, G.J.C. Seasonal changes in community composition and trophic structure of fish populations of five salt marshes along the Essex coastline, United Kingdom. Estuar. Coast. Shelf Sci. 2009, 85, 247-256. [CrossRef]

28. Desmond, J.S.; Zedler, J.B.; Williams, G.D. Fish use of tidal creek habitats in two southern California salt marshes. Ecol. Eng. 2000, 14, 233-252. [CrossRef]

29. West, J.M.; Zedler, J.B. Marsh-Creek Connectivity: Fish Use of a Tidal Salt Marsh in Southern California. Estuaries 2000, 23, 699. [CrossRef]

30. Laffaille, P. Composition of Fish Communities in a European Macrotidal Salt Marsh (the Mont Saint-Michel Bay, France). Estuar. Coast. Shelf Sci. 2000, 51, 429-438. [CrossRef]

31. Leitão, R.; Martinho, F.; Neto, J.M.; Cabral, H.; Marques, J.C.; Pardal, M.A. Feeding ecology, population structure and distribution of Pomatoschistus microps (Krøyer, 1838) and Pomatoschistus minutus (Pallas, 1770) in a temperate estuary, Portugal. Estuar. Coast. Shelf Sci. 2006, 66, 231-239. [CrossRef]

32. Mathieson, S.; Cattrijsse, A.; Costa, M.; Drake, P.; Elliott, M.; Gardner, J.; Marchand, J. Fish assemblages of European tidal marshes: A comparison based on species, families and functional guilds. Mar. Ecol. Prog. Ser. 2000, 204, 225-242. [CrossRef]

33. Basos, N. GIS as a Tool to Aid Pre- and Post-Processing of Hydrodynamic Models. Application to the Guadiana Estuary. Master's Thesis, Algarve University, Faro, Portugal, 2013.

34. Faria, A.M.; Borges, R.; Gonçalves, E.J. Critical swimming speeds of wild-caught sand-smelt Atherina presbyter larvae. J. Fish Biol. 2014, 85, 953-959. [CrossRef] [PubMed]

35. Faria, A.M.; Muha, T.; Morote, E.; Chícharo, M.A. Influence of starvation on the critical swimming behaviour of the Senegalese sole (Solea senegalensis) and its relationship with RNA/DNA ratios during ontogeny. Sci. Mar. 2011, 75, 87-94. [CrossRef]

36. Silva, L.; Faria, A.M.; Teodósio, M.A.; Garrido, S. Ontogeny of swimming behaviour in sardine Sardina pilchardus larvae and effect of larval nutritional condition on critical speed. Mar. Ecol. Prog. Ser. 2014, 504, 287-300. [CrossRef]

37. Gisbert, E.; López, M.A. First record of a population of the exotic mummichog Fundulus heteroclitus (L., 1766) in the Mediterranean Sea basin (Ebro River delta). J. Fish Biol. 2007, 71, 1220-1224. [CrossRef]

38. Feldmeth, C.R.; Waggoner, J.P. Field measurements of tolerance to extreme hypersalinity in the California killifish, Fundulus parvipinnis. Copeia 1972, 3, 592-594. [CrossRef]

39. Lockfield, K.C.; Fleeger, J.W.; Deegan, L. Mummichog, Fundulus heteroclitus, Responses to Long-Term, Whole-Ecosystem Nutrient Enrichment. Mar. Ecol. Prog. Ser. 2013, 492, 211-222. [CrossRef]

40. Elser, J.J.; Bracken, M.E.S.; Cleland, E.E.; Gruner, D.S.; Harpole, W.S.; Hillebrand, H.; Ngai, J.T.; Seabloom, E.W.; Shurin, J.B.; Smith, J.E. Global analysis of nitrogen and phosphorus limitation of primary producers in freshwater, marine and terrestrial ecosystems. Ecol. Lett. 2007, 10, 1135-1142. [CrossRef] [PubMed]

41. Posey, M.H.; Alphin, T.D.; Cahoon, L.; Lindquist, D.; Becker, M.E. Interactive effects of nutrient additions and predation on infaunal communities. Estuaries 1999, 22, 785-792. [CrossRef]

42. Lefeuvre, J.C.; Laffaille, P.; Feunteun, E. Do fish communities function as biotic vectors of organic matter between salt marshes and marine coastal waters? Aquat. Ecol. 1999, 33, 293-299. [CrossRef]

43. Elliot, M.; Hemingway, K.; Costello, M.J.; Duhamel, S.; Hostens, K.; Labropoulou, M.; Marshall, S.; Winkler, H. Links between fish and other trophic levels. In Fishes in Estuaries; Elliot, M., Hemingway, K.L., Eds.; Blackwell Science: Oxford, UK, 2002; pp. 54-123, ISBN 9780632057337.

44. Abraham, B.J. Species profiles: Life histories and environmental requirements of coastal fishes and invertebrates (Mid-Atlantic) mummichog and striped killifish. USFWS Biol. Rep. 1989, 82.

45. Hermoso, V.; Blanco-Garrido, F.; Prenda, J. Spatial distribution of exotic fish species in the Guadiana river basin, with two new records. Limnetica 2008, 27, 189-194.

46. Rocha, C.; Galvão, H.; Barbosa, A. Role of transient silicon limitation in the development of cyanobacteria blooms in the Guadiana estuary, south-western Iberia. Mar. Ecol. Prog. Ser. 2002, 228, 35-45. [CrossRef]

47. Secretariat of the Convention on Biological Diversity. Assessment and management of alien species that threaten ecosystems, habitats and species. Presented at the 6th Meeting of the Subsidiary Body on Scientific, Technical and Technological Advice, Montreal, QC, Canada, 12-16 March 2001.

48. Agência Portuguesa do Ambiente. Plano de Gestão da Região Hidrográfica do Guadiana $2016-2021$. Personal communication, 2015. 
49. Muus, B.J.; Dahlstrom, P. Guide Des Poissons D'eau Douce et Pêche; Quartier, A.A., Ed.; Delachaux \& Niestlé: Neuchâtel-Paris, France, 1968; 248p.

50. Whitehead, P.J.P.; Bauchot, M.L.; Hureau, J.C.; Nielsen, J.; Tortonese, E. Fishes of the North-Esatern Atlantic and Mediterranean; Whitehead, P.J.P., Ed.; UNESCO: London, UK, 1986; Volume 2, 1473p, ISBN 9230023086.

51. Russell, F.S. The Eggs and Planktonic Stages of British Marine Fishes; Academic Press: New York, NY, USA, 1976; 539p, ISBN 0126040508.

52. Ré, P. Ictioplânton Estuarino Da Península Ibérica (Guia de Identifição Dos Ovos E Estados Larvares Planctónicos; Câmara Municipal de Cascais: Cascais, Portugal, 1999; 163p, ISBN 972-637-065-5.

53. Elliott, M.; Dewailly, F. The structure and components of european estuarine fish assemblages. Aquat. Ecol. 1995, 29, 397-417. [CrossRef]

54. Pianka, E.R. The structure of Lizard Communities. Annu. Rev. Ecol. Syst. 1973, 4, 53-74. [CrossRef]

55. R Development Core Team. R: A Language and Environment for Statistical Computing; The R Foundation for Statistical Computing: Vienna, Austria, 2009.

56. Zhang, J. Miscellaneous Functions for Analysing Species Association and Niche Overlap, version 0.2.2. Species Association Analysis Package (SPAA), 2016.

(C) 2017 by the authors. Licensee MDPI, Basel, Switzerland. This article is an open access article distributed under the terms and conditions of the Creative Commons Attribution (CC BY) license (http://creativecommons.org/licenses/by/4.0/). 